\title{
Feasibility Study on the Issue of China's Pension Fund Investing Capital Market
}

\author{
Yun SUN \\ International Business Faculty, \\ Beijing Normal University, Zhuhai, \\ Zhuhai, China \\ samsunyun@163.com \\ Shaosong WANG* \\ * Corresponding Author \\ School of Business \\ Macau University of Science and Technology, \\ Macau SAR, China \\ sswang@must.edu.mo
}

\author{
Xun Zhao \\ School of Continuing Education, \\ Beijing Normal University, Zhuhai, \\ Zhuhai, China \\ 58107709@qq.com \\ Guisheng WU \\ Statistics Department \\ Capital Market Statistics and Monitoring Center, \\ Beijing, China \\ wugs@cmsmc.cn
}

\begin{abstract}
With the remarkable improvement of scientific and technological progress and social development, Chinese residents' living standard and the quality of life have been improved significantly. In addition, due to our unique family planning policy, the problem of population aging is getting increasingly serious. Meanwhile, pension issue has caused wide concern and needs to be solved immediately. Specifically, in the context of the European debt crisis as well as inflation, the problem of how to preserve or increase the market value of pension requires more attention. In this paper, we firstly introduce the background of the pension investment in China capital market, and describe the current operating conditions and the challenges of it. We collect data from OECD Global Pension Statistics, including 46 OECD countries, with the sample of proportion of investing into capital market related to total investments. We find that the traditional investment mode of China's basic old-age insurance cannot achieve the objective of maintaining and increasing the value these funds. In order to fully enjoy the benefits brought by national economic development, pension funds need to be invested into the capital market to achieve the goal of expanding profits.
\end{abstract}

Keywords-Aging of population; Pension; Capital market; Feasibility

\section{INTRODUCTION}

With the social and economic development of China and the advancement of medical care, the average life expectancy of the common people has been prolonged year by year. At the same time, due to the country's unique birth control policy, the aging of China's population has become increasingly serious. In 2014, the basic information of the elderly population reached 110.83 million in the national population aged 65 and above, and the old-age dependency ratio was $11.9 \%$, which was a $0.3 \%$ increase from the end of the 13 th year (citation). As the aging of the population becomes more prominent, a series of social problems that accompany it are also urgently needed. One of the most important issues is pensions. At present, pension funds that China can use to invest in capital markets mainly include corporate annuities and social security funds, while the basic social pension insurance funds, which account for the majority, are ignored by the capital market, especially the stock market. Under the influence of inflation and debt crisis and other unfavorable factors, a large number of retirees will rely on pension life; therefore, hundreds of billions of pensions need to maintain or increase the value, which puts a severe test on China's pension system. According to the current domestic research (citation), basic pension insurance funds can only invest in two ways, buying Treasury bonds or depositing bank accounts, respectively. However, the return is not optimistic. Consequently, how to maintain and increase the value of pensions for pension management becomes more important, since this is related to the 'live money' of the rest of the older people and should be paid more attention by the government.

On December 15, 2011, the Chairman of the China Securities Regulatory Commission GUO, Shuqing first introduced the pension funds into the market. Several months later, on March 20, 2012, the State Council approved that the National Council for Social Security Funds commissioned by the Guangdong Provincial Government to invest and manage the pension of urban employees in Guangdong Province by RMB 100 billion. Although risks and benefits coexist, there are many successful precedents in looking at the reform of the global pension system. Therefore, the investment in China's pension should take its essence to its dregs, based on the actual situation of China's pension investment to maintain value.

This paper analyzes the current status of pension investment in China, compares typical foreign cases, and adopts the latest data analysis. We collect data from OECD Global Pension Statistics, including 46 OECD countries, with the sample of proportion of investing into stock market related 
to total investments. Based on the empirical study, we find that the traditional investment mode of China's basic old-age insurance cannot achieve the objective of maintaining and increasing the value these funds. As a result, investing into capital market, such as stock and bond market, is an option for the operation and management of pension investment, and improves relevant theoretical systems. The other sections in this paper are as follows: Section II illustrates the relative literature. In Section III, we demonstrate the empirical study. The conclusion is in section IV.

\section{LITERATURE REVIEW}

To analyze the reasons for investing in pension capital markets, Xue (2014) pointed out that due to the aging problem, conversion to cost, the problem of 'empty accounts' becomes increasingly serious, and the risk of inflationary crisis and devaluation increases day by day. After introducing Canada's investment experience and issues, several suggestions were made for China's pension investment. Yang and Meng (2013) used the SWOT analysis method commonly used in strategic analysis to analyze the strengths, weaknesses, opportunities, and threats of pension reform in the context of the establishment of a pilot area in Guangdong, and weighed the advantages and disadvantages. On the basis of foreign experience, several suggestions have been made for the reform of China's pension market.

Jiang (2012) pointed out two issues for the issue of pensions in China: the status of foreign pension funds entering the capital market; foreign experience provides reference for China's pension funds to enter the capital market. To summary, the proportion of foreign pensions entering the market is far greater than that of China. Therefore, it is possible that China's pension could be benefit from the capital market. In this sense, the benefits of pension development are shared by the pension market to ensure that there is no problem in maintaining and increasing value. Meanwhile, we should also pay attention to the fact of the different conditions between domestic and abroad, as well as the operating methods.

Drawing on foreign investment models and experiences, Cai (2012) has updated the foreign pension investment management literature in accordance with the five parts of the investment system reform, channel, risk aversion, social benefits and analysis framework, to clarify the important controversies, analysis framework and enlightenment in the study of pension investment management, and pointed out that in the design and reform of China's pension system. Xu (2011) discussed the relationship between pensions and capital markets, designed a reasonable proportion of fund investment distribution, proposed countermeasures for improving the efficiency of pension investment and possible investment tool innovations, and expanded the range of funds that can be invested, thus increasing the performance of China's pension investment is $10 \%$.

From an investor's point of view, Jiang and Liang (2012) examine the scale and effect of the introduction of pensions in major countries from the perspective of international comparison, and then make a brief description based on the possible impacts of China's pension funds' entry into the

Funded by Program for Research Development of Beijing Normal University, Zhuhai, and International Business Faculty, (Project No. 201754021 and 201754024). market. Analysis of the size of funds, investment direction and other aspects, from which to find market investors investment opportunities. In view of the fact that the pension funds are currently in the expected stage of the market, investors should not blindly set this as the inflection point of the stock market and enter into heavy positions. On the other hand, investors should also pay attention to the utility brought by this information, seize the opportunity, and invest. Before the pension fund can be put into the market, it can lock in its own investment direction according to the possible investment direction of the pension, so as to realize the goal of retrenchment. In addition, the long-term investment and value investment need to pay attention to the issue.

Risks and benefits go hand in hand. External risks mainly include structural risks, market risks, and supervision risks; internal risks mainly include agency risks and operational risks. Therefore, China's pension funds must invest in the capital market, and they should also pay attention to the risks they bear after seeing their ability to make profits. They must also take appropriate coping mechanisms to control risks from all aspects of internal and external risks. With regard to the benefits of pensions entering the capital market, Li (2012) demonstrated the need for pensions to enter the market from a variety of perspectives by introducing the concept of pensions and the status quo. The first is to help solve the current increase in the pension gap. The problem of low yields; the second is to help solve other social and economic problems caused by the pension system. Based on the experience of foreign countries and taking full consideration of China's actual national conditions, we have put forward specific recommendations for the formulation of the pension market entry program.

Although the current domestic research on pension investment capital markets is mostly positive, many of them have voiced doubts. He and Meng (2015) analyzed the pension investment capital market and emphasized that the obstacles to the entry of pension insurance funds are largely due to the disadvantages of China's stock market. Therefore, many scholars and experts will consider that pensions into the stock market are not different from the current situation. Enter "Slot Machine" 14. Some experts believe that if large-scale pensions are put into the market, it will have an impact on a capital market such as China's immature stock market, and institutions that are entrusted by the government to manage pension funds are likely to interfere directly or indirectly with internal decision-making. What is more, it will make use of this to achieve its political goals rather than economic goals and so on.

Through the above studies, we can know that the pension investment capital market does have a lot of room. At present, the domestic research situation is to study the relationship between the pension investment capital market or the pension and capital markets. It mainly combines the theory and experience of foreign countries, and combines the existing actual conditions in China to carry out pension investment into the market. Based on these, we provide the hypothesis for this paper as follows:

Ho: It is valuable to invest the Chinese pension into capital market, to maintain or even increase the market value. 
III. EMPIRICAL STUDY

A. Analysis of the proportion of pension holdings and total investment rate
We use SPSS software and select a representative pension investment structure table for 46 OECD and non-OECD countries during 2013. The data comes from OECD Global Pension Statistics (See Table I).

TABLE I. COUNTRIES PENSION INVESTMENT STRUCTURE IN 2013

\begin{tabular}{|c|c|c|c|c|c|}
\hline & Shares & Bills and bonds & Cash and Deposits & Other & Total Investment \\
\hline United States & 49.5 & 20.8 & 0.9 & 28.9 & 83.0 \\
\hline Australia & 49.1 & 8.4 & 17.7 & 24.8 & 103.3 \\
\hline Chile & 42.1 & 56.7 & 0.3 & 0.9 & 62.2 \\
\hline Poland & 41.5 & 51.8 & 6.0 & 0.8 & 18.6 \\
\hline Belgium & 39.0 & 42.0 & 3.9 & 15.1 & 5.2 \\
\hline Finland & 38.2 & 31.1 & 4.0 & 26.7 & 50.8 \\
\hline Netherlands & 37.5 & 42.9 & 3.3 & 16.3 & 166.3 \\
\hline Norway & 35.5 & 57.2 & 2.3 & 4.9 & 8.3 \\
\hline Austria & 34.4 & 48.1 & 12.8 & 4.7 & 5.8 \\
\hline Estonia & 33.8 & 48.6 & 17.4 & 0.1 & 9.6 \\
\hline Canada & 31.7 & 34.6 & 3.5 & 30.1 & 71.3 \\
\hline Switzerland & 29.2 & 33.6 & 8.2 & 29.0 & 119.0 \\
\hline UK & 24.1 & 30.7 & 3.3 & 41.9 & 100.7 \\
\hline Mexico & 23.6 & 75.1 & 0.9 & 0.3 & 14.8 \\
\hline Iceland & 22.7 & 52.8 & 7.6 & 17.0 & 148.7 \\
\hline Luxembourg & 21.5 & 68.7 & 5.0 & 4.8 & 2.1 \\
\hline Portugal & 20.2 & 44.0 & 12.0 & 23.7 & 9.1 \\
\hline Italy & 19.2 & 48.0 & 3.6 & 29.2 & 6.1 \\
\hline Sweden & 15.4 & 75.2 & 3.6 & 5.8 & 9.5 \\
\hline Denmark & 15.3 & 66.4 & 0.5 & 17.8 & 42.8 \\
\hline Turkey & 14.0 & 69.0 & 0.0 & 17.0 & 4.9 \\
\hline Japan & 11.2 & 37.1 & 5.5 & 46.1 & 29.3 \\
\hline Spain & 10.4 & 63.3 & 15.0 & 11.3 & 9.0 \\
\hline Israel & 6.3 & 73.7 & 5.0 & 15.0 & 50.4 \\
\hline Hungary & 6.2 & 83.1 & 8.0 & 2.6 & 4.1 \\
\hline Greece & 5.4 & 68.4 & 24.6 & 1.6 & 0.1 \\
\hline Germany & 4.4 & 51.8 & 3.7 & 40.0 & 6.2 \\
\hline Slovak & 1.3 & 74.8 & 23.1 & 0.8 & 10.0 \\
\hline Slovenia & 1.2 & 78.1 & 17.2 & 3.5 & 4.0 \\
\hline Czech Republic & 0.3 & 86.5 & 10.6 & 2.6 & 7.7 \\
\hline Korea & 0.0 & 9.0 & 56.5 & 34.6 & 6.5 \\
\hline Hong Kong, & 60.5 & 22.7 & 12.9 & 4.0 & 37.5 \\
\hline Pakistan & 37.3 & 39.5 & 19.2 & 3.9 & 0.0 \\
\hline Colombia & 31.5 & 52.6 & 2.8 & 13.0 & 18.2 \\
\hline Peru & 30.3 & 51.2 & 18.6 & 0.0 & 18.7 \\
\hline Brazil & 27.9 & 53.2 & 0.1 & 18.8 & 13.3 \\
\hline Kenya & 24.3 & 39.5 & 7.3 & 28.8 & 18.3 \\
\hline Romania & 16.5 & 74.8 & 8.6 & 0.1 & 2.3 \\
\hline
\end{tabular}




\begin{tabular}{|c|c|c|c|c|c|}
\hline \multicolumn{6}{|c|}{ Table I, cont } \\
\hline Jamaica & 15.3 & 70.1 & 1.9 & 12.6 & 21.3 \\
\hline Bulgaria & 14.3 & 60.4 & 21.3 & 4.0 & 8.7 \\
\hline Thailand & 14.2 & 57.2 & 27.8 & 0.7 & 6.3 \\
\hline Malta & 13.1 & 32.1 & 23.2 & 31.6 & 17.0 \\
\hline Serbia & 2.8 & 85.1 & 11.7 & 0.4 & 0.5 \\
\hline Latvia & 1.0 & 66.0 & 32.4 & 0.6 & 1.0 \\
\hline Costa Rica & 0.0 & 100.0 & 0.0 & 0.0 & 11.0 \\
\hline Albania & 0.0 & 96.7 & 1.9 & 1.4 & 0.0 \\
\hline
\end{tabular}

We checked the relationship between proportion of investment in the pension fund and the total investment rate via correlation test. The results can be found from the Pearson correlation test, indicating the coefficient is 0.431 . In addition, the two-sided significance value was $0.003<0.05$, indicating that the irrelevance of the two was rejected at a significant level of 0.05 . Moreover, it can be found that the Spearman rank correlation coefficient between the ratio of pension investment to stocks and the investment return rate is 0.497 , and its sig. (bilateral) $=0.000<0.05$. In summary, there is a significant positive correlation between the proportion of pension investment stocks and the total investment rate.

\section{B. Feasibility Analysis of China's Pension Investment in Stock Market}

In the research of investment issues, the nominal rate of return cannot reflect the actual rate of return. It should consider that the large rate of inflation has a significant impact on the actual income. Therefore, according to the formula: actual rate of return $=$ nominal rate of return - inflation rate, the actual income can be obtained The rate, while the inflation rate in Table II is represented by the increase in CPI.

To study the feasibility of China's pension investment capital market, the actual annual average return rate in Table II is the average of the actual rate of return from 2001 to 2013. The investment risk is the standard deviation of the actual rate of return. As can be seen from Table II, pure investment in government bonds or deposit in banks is a conservative method that helps to avoid risks, but it does not enjoy the benefits of stock dividends. The results of the investment operation of the National Social Security Fund gave us a good explanation. The actual annual average investment return rate for the 13 years from 2001 to 2013 was $8.13 \%$, the average investment risk was $12.80 \%$, and the objective of maintaining and increasing the value of pensions successfully arrived. It can be concluded that investing in China's pension fund through an effective portfolio of securities can fully preserve and increase value.

TABLE II. RATE OF RETURN OF CHINESE BANK INTERESTS, STOCK AND T-BILL FROM 2001 TO 2013

\begin{tabular}{|c|c|c|c|c|c|c|c|}
\hline Year & $\begin{array}{c}\text { Three-year } \\
\text { bank deposits } \\
\text { nominal } \\
\text { interest rate }\end{array}$ & $\begin{array}{c}\text { Three-year } \\
\text { Treasury Bond } \\
\text { nominal interest } \\
\text { rate }\end{array}$ & $\begin{array}{l}\text { Shanghai stock } \\
\text { index yield }\end{array}$ & inflation rate & $\begin{array}{c}\text { Three-year } \\
\text { bank deposits } \\
\text { the actual } \\
\text { interest rate }\end{array}$ & $\begin{array}{c}\text { Three-year } \\
\text { Treasury Bond } \\
\text { actual interest } \\
\text { rate }\end{array}$ & $\begin{array}{l}\text { Real stock return } \\
\text { on the Shanghai } \\
\text { stock exchange }\end{array}$ \\
\hline 2001 & 2.70 & 2.89 & -20.76 & 0.70 & 2.00 & 2.19 & -21.46 \\
\hline 2002 & 2.52 & 2.22 & -17.39 & -0.80 & 3.32 & 3.02 & -16.59 \\
\hline 2003 & 2.52 & 2.32 & 11.10 & 1.20 & 1.32 & 1.12 & 9.90 \\
\hline 2004 & 3.24 & 3.37 & -15.15 & 3.90 & -0.66 & -0.53 & -19.05 \\
\hline 2005 & 3.24 & 3.24 & -7.91 & 1.80 & 1.44 & 1.44 & -9.71 \\
\hline 2006 & 3.69 & 3.14 & 121.63 & 1.50 & 2.19 & 1.64 & 120.13 \\
\hline 2007 & 4.77 & 3.66 & 149.88 & 4.80 & -0.03 & -1.14 & 145.08 \\
\hline 2008 & 4.21 & 5.74 & -66.18 & 5.90 & -1.69 & -0.16 & -72.08 \\
\hline 2009 & 3.33 & 3.73 & 86.49 & -0.70 & 4.03 & 4.43 & 87.19 \\
\hline 2010 & 4.00 & 3.73 & -13.98 & 3.30 & 0.70 & 0.43 & -17.28 \\
\hline 2011 & 4.75 & 5.43 & -21.68 & 5.40 & -0.65 & 0.03 & -27.08 \\
\hline 2012 & 4.45 & 5.43 & 3.17 & 4.80 & -0.35 & 0.63 & -1.63 \\
\hline 2013 & 4.25 & 4.76 & -6.50 & 3.25 & 1.00 & 1.51 & -9.75 \\
\hline
\end{tabular}

\section{CONCLUSION}

The issue of China's pension has been noticed for a while, and it is important to fix the issue of increasing the value of these pensions. In this paper, we test 46 OECD countries and find a significant positive relationship between the proportion of investment in the pension fund and the total investment rate, indicating that it is a good method to invest Chinese pensions into capital market, such as stock or bond market. However, related risk should also been controlled for, in order to maintain the risk premium for these pensions. Future studies are recommended to control for the macroeconomics background, which could enable the results more accurate. 


\section{REFERENCES}

[1] Xue, J., "The Urgency of China's Pension Fund Entering the Capital Market and Investment Advice," Chinese and Foreign Entrepreneurs, 2014, 16:130-131.

[2] Yang, T. and Meng, N., "Feasibility Analysis and Policy Suggestions on China's Pension Market Access," Securities \& Futures of China, 2013, 08:55.

[3] Jiang, D., "A Brief Discussion on the Foreign Pension Entering the Capital Market for China's Reference Role," Guide to Business, 2012, 07:21-22.

[4] Jiang, X. and Liang, L., "On the Introduction of Pension into the Market," Securities \& Futures of China, 2012,02:37.

[5] He, L., and Meng Z., "Analysis on the Possibility and Obstacle of Listing Pension Fund," Journal of Yunnan Agricultural University (Social Science Edition), 2015,02:25-30. 